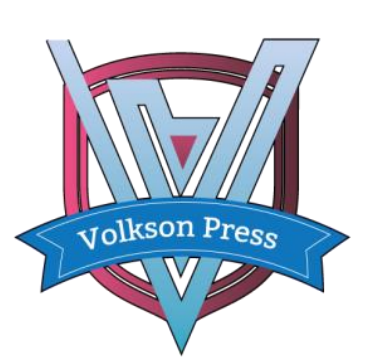

Contents List available at VOLKSON PRESS

Economics \& Management Innovations(EMI)

DOI : http://doi.org/10.26480/icemi.02.2018.41.43

ISBN: 978-1-948012-14-0

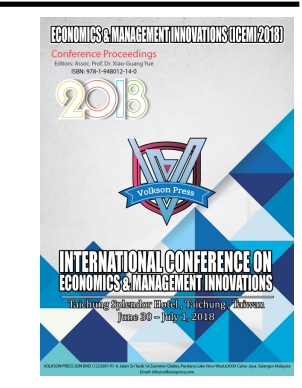

\title{
THE IMPACT OF NEW TRADE BARRIERS ON CHINA'S EXPORT TRADE
}

\author{
Xue Liu \\ Department of international trade, Nanjing University of Science and Technology, 200 Xiaolingwei, Xuanwu District, Nanjing, Jiangsu Province, \\ China. \\ *Corresponding Author Email: 1114592521@qq.com
}

This is an open access article distributed under the Creative Commons Attribution License, which permits unrestricted use, distribution, and reproduction in any medium, provided the original work is properly cited.

\section{ARTICLE DETAILS}

\section{Article History:}

Received 26 June 2018 Accepted 2 July 2018 Available online 1 August 2018

\section{ABSTRACT}

With the completion of the eight rounds of negotiations on the GATT, the world has formed a trend to promote trade freedom. Tariffs under the influence of the WTO have been significantly reduced. The traditional role of tariff barriers has gradually declined. At the same time, non-tariff barriers and new trade barriers began to rise. The emergence of new trade barriers centered on technical trade barriers has brought unavoidable impact on China's export trade. For china, the emergence of trade barriers is an opportunity and a challenge. This article analyzes the impact of new trade barriers on China's export trade in terms of technical barriers, blue trade barriers and green trade barriers through comparative analysis. The analysis concluded that the new type of trade barriers is conducive to promoting China's technological upgrading and improving the social and natural environment. On the other hand, as a new type of flexible trade barrier, it will inevitably hinder China's export trade. For China, both the government and the enterprise must pay attention to the impact of new trade barriers.

\section{KEYWORDS}

New trade barriers, Technical barriers to trade, Green trade barrier, Blue trade barriers.

\section{INTRODUCTION}

First, with the establishment of the WTO organization and the completion of eight rounds of negotiations, trade liberalization has increasingly become a worldwide trend. As a result, the level of tariffs has been significantly reduced, and the role of tariff barriers has also dropped. Some countries or regions are looking for ways to protect their own trade interests or prevent other countries from entering their domestic markets and seek alternative trade barriers. New types of trade barriers rose quickly. Second, with the development of economy and the progress of science and technology, people's awareness of environmental protection, human rights awareness, and awareness of animal welfare have gradually increased. People will not only care about the quality and price of the product, but also care about whether the product's production conforms to the concepts of humanity and environmental protection. People have higher and higher requirements for the technical standards of products, thus providing external conditions for the development of new types of trade. Finally, various new types of trade barriers, such as technical trade barriers, green trade barriers, etc., due to their own characteristics of flexibility, concealment, etc., make them more easily used by some countries as tools for trade barriers. In this environment, new trade barriers have gradually developed. After China's accession to the WTO, China's participation in international trade has become more and more numerous, and it has become a world trade power. While participating in international trade. China's export trade will inevitably face the threat of new trade barriers

Literature on technical trade barriers. A researcher pointed out the status and characteristics of the technical trade barriers faced by China's export trade and explained the countermeasures that can be implemented and affected by the technical trade barriers [1]. He believes that technical trade barriers are unavoidable, and what we must do is respond positively and participate in formulating rules to take the initiative. Margaret A. Young evaluated a series of market-related measures that are compatible with international trade law, including the General Agreement on Tariffs and Trade (GATT) and the Agreement on Technical Barriers to Trade [2].

Literature on green trade barriers. Qiu Fengfeng analyzed the form and impact of China's current green trade [3]. He believes that China should find green businesses and formulate new technical standards to deal with green barriers. Or direct overseas investment to bypass green trade barriers. Zhang introduced the current status of animal welfare at home and abroad and explained that animal welfare has become a new international trade barrier. It will affect the export of related industries in our country [4]. Therefore, we should take the establishment of animal welfare legal system, the formulation of industrial standards and other ways to deal with the impact of animal welfare barriers on China's export trade. Based on the significance of green barriers, analyzing green barriers can promote the sustainable development of our foreign trade and propose countermeasures against anti-green barriers.

Document on blue trade barriers. Some researchers gave a brief introduction to the blue trade barriers and SA8000 and explained its impact on Chinese companies. He believes that the blue trade barriers have a double impact on Chinese enterprises. On the one hand, it will make some foreign trade companies difficult to manage, on the other hand, it will help solve labor problems under the globalization and promote social progress. Therefore, enterprises should enhance the value creativity and value-added products of their companies and stimulate their operational vigor. Introduced the influencing factors and main contents of social barriers. He believes that the core issue of social barriers is labor standards. Under this circumstance, our country must deeply analyze the status quo of our country's labor combined with actual conditions and formulate corresponding countermeasures so as to promote the development of China's foreign trade. 


\section{THE CONCEPT OF NEW TRADE BARRIERS}

New trade barriers are relative to traditional trade barriers. Traditional trade barriers are the general term for traditional tariff barriers and traditional non-tariff barriers. Including tariffs, quotas, anti-dumping, anti-subsidy, permits, etc. The new trade barriers are centered on technical trade barriers, including social barriers and green barriers. Traditional trade barriers mainly restrict the free flow of goods in the international market on the commercial interests such as the price and quantity of commodities. Compared with traditional trade barriers, new trade barriers consider more non-commercial interests than commodity prices and quantities. Factors such as social and environmental benefits. In these aspects, the restrictions on the free flow of goods in the international community.

This is the most fundamental feature of new-type trade barriers relative to traditional trade barriers. In addition, the new trade barriers also have the following characteristics: First of all, both sides. Unlike the traditional trade barriers, which are simply aimed at restricting trade, new trade barriers have the name of protecting human health and safety. On the one hand, they have the benefit of the human society, and on the other, they are liable to cause problems in some countries due to trade restrictions. Using it as a hidden trade barrier is not conducive to the free development of international trade. Second, complexity.

Due to the two sides of the new type of trade barrier, the definition of it has complexity. It is difficult to determine whether a policy is precisely for the purpose of protecting the safety and health of human beings or for restricting trade, whether it is the result of protecting human safety or the result of restricting trade. In the end, diversity. New trade barriers not only involve the healthy development of human society, but also the welfare of animals, such as animal welfare barriers. Not only involves the environmental interests of the contemporary people, but also takes care of the interests of future generations. Therefore, diversity is also an important feature of the new type of trade barriers.

The main types of new trade barriers include technical barriers to trade, green trade barriers and blue trade barriers. This article mainly explores the impact of new trade barriers on China's export trade from these three aspects.

\section{THE IMPACT OF NEW TRADE BARRIERS ON CHINA'S EXPORT TRADE}

As new types of trade barriers have increasingly become the main method of trade barriers in international trade, China's export trade is also unavoidably affected. This kind of influence is two-sided. On the one hand, it has a positive effect. On the other hand, it has a negative effect. In the following, this article will introduce in detail the positive and negative aspects of the impact of new trade barriers on China's export trade.

\subsection{Positive Effects of New Type of Trade Barriers on China's Export Trade}

First of all, because TBT sets barriers through high standards and high requirements, for export companies in China, in order to deal with TBT of developed countries, they have to improve technology, improve packaging, etc. to improve the technical level of products. In addition, in order to be invincible in the international competition, our export enterprises need to improve production efficiency and product quality, which will help improve the international competitiveness of our export products. As for those industries that cannot make technological improvements, we will also be involved in international trade. Was eliminated. Therefore, objectively speaking, technical trade barriers are conducive to optimizing China's export industrial structure.

Second, since TBT is mainly set up by developed countries or regions such as the United States, Japan, and the European Union with their technological advantages, while TBT suffers, China's export enterprises are also inevitably going to understand the technological level and technical standards of developed countries. The government also inevitably needs to understand the technical regulations, rules and regulations concerning trade of developed countries and international organizations. This is of great significance for Chinese enterprises and governments to increase their awareness of international technical regulations and improve China's own technical laws and regulations. And influence.

As mentioned earlier, green trade barriers are barriers set in the name of protecting human health, resources, and the environment. Therefore, objectively, green trade barriers have a positive effect on improving China's health, resources, and the environment. There are several reasons why green trade barriers have a catalytic effect. First of all, like technical barriers to trade, green trade barriers are also conducive to optimizing the structure of China's export enterprises. Enterprises that cannot adapt to high environmental standards will lose competitiveness and will eventually be eliminated by the market. They can improve production processes and focus on products for humans.

Companies with health and environmental impacts can survive the competition. Second, green trade barriers can increase the environmental awareness of our government and export companies. Finally, green trade barriers are not exclusive to a country. Any country can implement green trade barriers in a proper name. When China suffers from green trade barriers, our country's corporate governments and enterprises are also aware of improving our environmental standards. The importance of resource standards.

Blue barriers, also known as social trade barriers, also have a positive impact on China's export trade objectively. The main content of social trade barriers is the SA8000 standard, which is the working time, rights, and treatment of workers. Guarantees and so on have set minimum requirements. First of all, China's implementation of the SA8000 standard is conducive to improving the working conditions and labor relations of workers. We know that although there are clear regulations on the rights and interests of workers in the "Labor Law" of China, some enterprises infringe on the rights and interests of workers. The implementation of the SA8000 standard obliges companies to respect the legitimate rights and interests of workers, and at the same time, it also enables workers to feel the people-centered concept and increase their enthusiasm for work. Second, blue trade barriers are conducive to improving China's labor laws and regulations.

While subjecting to blue trade barriers, some specific provisions in the SA8000 also provide a basis and reference for the improvement of China's labor laws. The Chinese government will also see the gap between China's laws and regulations and international regulations and enhance the awareness of the improvement of the country's labor laws. Finally, social trade barriers are also conducive to the healthy development of enterprises. An enterprise that does not respect the legitimate rights and interests of workers not only does not have a good business image, but also cannot achieve long-term healthy development. Even if it is fortunate to have short-term development, it must be deformed because it cannot obtain employee loyalty and a good corporate image. . Therefore, objectively, the existence of blue trade barriers to a certain extent is conducive to the long-term healthy development of China's export enterprises.

\subsection{The New Trade Barriers Have a Negative Impact on China's Export Trade}

Technical barriers to trade will obviously reduce the export volume of exporting countries and reduce their share of the world market. When technical requirements increase, products with lower technological levels are forced to exit the market because they cannot meet the technical requirements, so that the number of exports of exporting countries will decrease. If the eliminated companies want to maintain their share of the world market, they must improve their technologies and increase their investment. Ultimately, they will increase costs, increase prices, and reduce international competitiveness. The final result is not only to reduce the export volume of exporting countries and to reduce market share, but 
also to increase the burden on domestic consumers and the competitiveness of products in the domestic market. Therefore, the implementation of TBT is not conducive to the development of China's export enterprises.

As a kind of technical trade barrier, green trade barriers have other influences besides the adverse effects of technical trade barriers. For example, because each country or region has different economic development status, resource utilization, residents' environmental awareness and resource awareness, and congenital natural environment, developed countries can rely on their economic development advantages, scientific and technological level advantages, etc. China implements green trade barriers. It is obviously unfair to use high standards applicable to developed countries to require developing countries, because in the early stages of industrialization, developed countries were also the accumulation of capital in return for resource waste and environmental pollution. Nowadays, developed countries have conditions for environmental governance and scientific utilization of resources, and they have conditions for implementing high-standard environmental requirements. However, during this period, the economic base of developing countries is still weaker than that of developed countries.

Developing countries need to complete industrialization and capital. Accumulation, during this period, the restrictions on green trade barriers by developing countries will widen the gap between developed and developing countries and hinder the normal economic development of developing countries. As the largest developing country, China cannot properly develop and utilize resources when it suffers from green trade barriers, and it is difficult for primary products that have advantages to gain advantages. High-tech and technological products are few and are hindered by the technical trade barriers of developed countries. Therefore, the green trade barriers will cause unfair pressure on the production and livelihood of Chinese enterprises, and ultimately hinder China's export trade and economic development.

China is a country with abundant labor resources. The demographic dividend is a major advantage of economic development, and the products exported by China are mostly labor-intensive products. The blue standard with the SA8000 standard as the core is bound to hinder the development of China's advantages. Excessive demands on the laborer's environment will, on the one hand, result in the exclusion of China's labor-intensive export products. On the other hand, companies must seek SA8000 certification in order to obtain foreign orders. This requires a significant amount of certification costs for companies. In particular, small and medium-sized enterprises lack sufficient financial resources, lose a lot of orders when they fail to obtain certification, and increase expenditures in order to increase employees' welfare through certification. This will increase the export costs of enterprises, and the increase in costs will inevitably affect the Chinese enterprises. International Competitiveness

\section{CONCLUSION}

Both technical trade barriers, green trade barriers, and blue trade barriers, as a type of new trade barrier, have a profound impact on China's export trade. This kind of influence has both positive and negative aspects. On the one hand, it is conducive to promoting China's technological upgrading and improving the social environment and the natural environment. On the other hand, as a new type of flexible trade barrier, it will inevitably hinder China's export trade. For our country, both the government and the enterprise must pay attention to the impact of new trade barriers. Not only for the three mentioned in the article, but also other types of new trade barriers such as non-market economic status barriers, electronic waste disposal barriers, etc. should also be given equal attention.

We must take advantage of positive influences, seize opportunities, and actively guide the positive role of new-type trade barriers. We must actively respond to negative impacts and handle them with caution. This part of the improvement should be open-minded to learn from advanced countries. Malicious obstacles to trade should be good at using rules to argue against arguments, protect our legitimate trade rights and interests, safeguard our country's market position, and promote the long-term healthy development of China's economy. Only by facing up to the impact of new-type trade barriers on China's export enterprises, seizing the opportunity to improve the quality of economic development, and adopting a positive attitude to meet the challenges, can China's export trade stand in the world market.

\section{ABOUT THE AUTHORS}

Xue Liu, a native of Suzhou, Anhui Province, China, is currently a graduate student at the Nanjing University of Science and Technology in 2017, specializing in international trade. under the tutelage of Professor Yu lan $\mathrm{Du}$.

\section{REFERENCES}

[1] Qing, G. 2010. On the Impact of Technical Trade Barriers on China's Export Trade and Countermeasures. Science and Technology Information.

[2] Young, M.A. 2016. International trade law compatibility of marketrelated measures to combat illegal, unreported and unregulated (IUU) fishing. Marine Policy.

[3] Roufeng, Q. 2010. On the Impact of Green Trade Barriers on China's Foreign Trade and Countermeasures. Gansu Science and Technology.

[4] Yujie, Z. 2007. The Influence of Blue Trade Barriers on Chinese Enterprises and Countermeasures. Mechanical Management and Development. 